\title{
CORRELATION OF CELL-ENVELOPE PHENOTYPES OF NEISSERIA GONORRHOEAE WITH SITE OF INFECTION AND SEROGROUP
}

\author{
Katherine G. ReID, JANet Warbrick AND H. Young \\ Department of Bacteriology, Edinburgh University Medical School, Teviot Place, \\ Edinburgh EH8 $9 A G$
}

\begin{abstract}
SummarY. The envelope phenotypes and coagglutination (CoA) W serogroups of 301 unselected clinical isolates of Neisseria gonorrhoeae were studied. Of the 287 isolates from infections acquired in the Edinburgh area, $252(88 \%)$ were of the wild-type phenotype, $17(6 \%)$ were of Env phenotype with increased permeability of the cell envelope, and $18(6 \%)$ were of Mtr phenotype with reduced permeability of the cell envelope. Mtr strains were isolated significantly more often from homosexual men than from heterosexual men and women $(p<0.001)$. Of the isolates from homosexual men there were considerably fewer Mtr phenotypes among rectal isolates than among urethral and throat isolates. All isolates from homosexual men, $57 \%$ from heterosexual men and $52 \%$ from women were of CoA serogroup WII (including WII/ WIII). Although the Mtr phenotype was strongly associated with serogroup-WII isolates from homosexual men, there was no such correlation between the Mtr phenotype and serogroup-WII isolates from heterosexual patients. It is suggested that hydrophobic compounds in the rectal environment are not the major factor in selecting serogroupWII strains of Mtr phenotype associated with homosexually acquired infection. The hypothesis that the Mtr phenotype and serogroup WII are selected independently as a result of a more general selective pressure such as antibiotic usage, common to all infected sites, is discussed.
\end{abstract}

\section{INTRODUCTION}

Cell-envelope mutations of Neisseria gonorrhoeae alter the organism's permeability and hence its sensitivity to various hydrophobic agents, including antibiotics (Maness and Sparling, 1973; Maier et al., 1974, 1975a and $b$ ).

Two separate mutations of this sort designated env (Maness and Sparling, 1973) and $m$ tr (Maier et al., 1974) influence the organism's sensitivity to these agents by altering both the amount of a minor protein (mol. wt 52 000) and peptidoglycan cross- 
linkage in the outer membrane (Guyman et al., 1978). Thus an env mutant, which has increased membrane permeability, is markedly more sensitive (hypersensitive) and an mtr mutant, which has reduced permeability, is much more resistant than a representative wild-type strain. The $e n v$ mutation suppresses the $m t r$ locus if the two occur in the same strain (Sarubbi et al., 1975). Gonococci with mtr mutations have been associated with homosexually-acquired infections (Morse et al., 1982).

Gonococci can be divided into three serogroups-WI, WII and WIII-by coagglutination (CoA) serogrouping (Sandstrom and Danielsson, 1980). CoA depends on the principle that immunoglobulin $\mathrm{G}$ binds by its $\mathrm{Fc}$ portion to protein $\mathrm{A}$ on the surface of Staphylococcus aureus leaving the Fab site free to bind with the corresponding or related antigen to produce a coagglutination matrix easily visible to the naked eye. In gonococcal serogrouping, specific antibody raised against reference strains of gonococci (Johnston et al., 1976) are selectively absorbed to produce coagglutination reagents which define the three major serogroups, WI, WII and WIII.

Strains of CoA serogroup WII have been associated with homosexually-acquired infection (Bygdeman, 1981a; Reid and Young, 1984) and reduced sensitivity to antibiotics (Bygdeman, 1981 b). Strains isolated from homosexual men often have both the $m t r$ and CoA serogroup WII characteristic (Morse et al., 1982). Although both confer resistance to antibiotics they represent two separate loci (Morse et al., 1982).

It has been suggested that the mtr mutation and CoA serogroup WII are selected by the rectal environment, which is rich in hydrophobic molecules. Accordingly, the present study was undertaken to increase our understanding of the role of different anatomical sites within the host in the selection of gonococcal strains with particular outer-membrane properties.

\section{MATERIALS AND METHODS}

Clinical Isolates. During the period July 1983 to May 1984, 301 isolates of N. gonorrhoeae were obtained from patients attending the Department of Genito-Urinary Medicine, The Royal Infirmary, Edinburgh. Of these strains, 14 were from patients who had acquired their infections either elsewhere in Britain or abroad. All isolates were identified as $N$. gonorrhoeae by the rapid carbohydrate utilisation test (Young et al., 1976).

Reference Strains. $N$. gonorrhoeae strains with known genotypes were kindly supplied by $\mathrm{Dr}$ P. F. Sparling, University of North Carolina, Chapel Hill, USA. These were FA140 (pen A2 mtr2 pen B2), FA102 (pen A2), FA19 (wild type), BR87 (env-2 str-7 pen A2 mtr-2 pen B2) and FA136 (pen A2 mtr-2). All strains were maintained on MNYC medium (Young, 1978) and envelope phenotypes were determined on the same medium lacking selective antibiotics (SMNYC medium).

Determination of cell-envelope phenotype. Each isolate was tested for sensitivity to the following hydrophobic compounds: erythromycin (Abbot Laboratories Ltd, Queenborough, Kent ME11 5EL), fusidic acid (Leo Laboratories Ltd, Princes Risborough, Bucks), Triton X100 (Fisons Scientific Apparatus, Loughborough, Leics) and crystal violet (Koch-Light Laboratories, Colnbrook, Berks).

A 19-point hand-held replicator (Mast Laboratories Ltd, Mast House, Serby Road, Bootle, Merseyside) was used to seed separate plates of SMNYC medium containing: erythromycin (doubling concentrations from 0.015 to $2.0 \mathrm{mg} / \mathrm{L}$ ); crystal violet (doubling concentrations from 0.5 to $4.0 \mathrm{mg} / \mathrm{L})$; fusidic acid $(0.03,0.25$ and $0.5 \mathrm{mg} / \mathrm{L}) ;$ and Triton $\mathrm{X}-100(0.06,1.0$ and $2.0 \mathrm{~g} / \mathrm{L})$. The inoculum was $c .10^{5} \mathrm{cfu}$ of an overnight culture of each test strain.

Each batch of plates was set up in duplicate and included the reference strains FA140, BR87, FA19 and FA136. After incubation for $48 \mathrm{~h}$ at $37^{\circ} \mathrm{C}$ in air with $\mathrm{CO}_{2} 10 \%$, plates were examined and the MIC determined as the lowest concentration of each agent that prevented visible growth. 
Strains with the following MICs, which were given by the Mtr reference strains FA140 and FA136, were designated the Mtr phenotype: erythromycin $\geqslant 0.5 \mathrm{mg} / \mathrm{L}$, fusidic acid $\geqslant 0.5 \mathrm{mg} / \mathrm{L}$, crystal violet $\geqslant 2.0 \mathrm{mg} / \mathrm{L}$ and Triton $X-100 \geqslant 2.0 \mathrm{~g} / \mathrm{L}$. Strains with the following MICs, which were given by the Env reference strain BR87, were designated the Env phenotype: erythromycin $\leqslant 0.06 \mathrm{mg} / \mathrm{L}$, fusidic acid $\leqslant 0.03 \mathrm{mg} / \mathrm{L}$, crystal violet $\leqslant 0.5 \mathrm{mg} / \mathrm{L}$ and Triton $X-100 \leqslant 0.06 \mathrm{~g} / \mathrm{L}$. The wild-type reference strain FA 19 had the following MICs: erythromycin $0.12 \mathrm{mg} / \mathrm{L}$, fusidic acid $0.25 \mathrm{mg} / \mathrm{L}$, crystal violet $1.0 \mathrm{mg} / \mathrm{L}$, and Triton X-100 $1.0 \mathrm{~g} / \mathrm{L}$. Test strains with erythromycin MICs of $0 \cdot 12-0.25 \mathrm{mg} / \mathrm{L}$ were designated wild type.

Serogrouping by coagglutination. Coagglutination reagents defining CoA serogroups WI, WII, WIII were prepared and isolates serogrouped as described by Reid and Young (1984).

Statistical analysis. Significance was tested by the $\chi^{2}$ method with Yates's correction.

\section{RESULTS}

Table I shows the distribution of cell-envelope phenotypes among isolates from infections acquired in the Edinburgh area by homosexual contact. There is a highly significant difference in the proportion of wild-type to Env and Mtr phenotypes when gonococcal isolates from 20 homosexual men are compared with those from 116 heterosexual men $\left(\chi^{2}=23.96 ; p<0.001\right)$ and 151 women $\left(\chi^{2}=25.89 ; p<0.001\right)$. There is no such significant difference when isolates from heterosexual men and women are compared $\left(\chi^{2}=0.01 ; p=0.9\right)$. The envelope phenotypes of fourteen isolates from infections acquired outwith the Edinburgh area are given in table II. Seven $(50 \%)$ of these 14 isolates were of the Mtr phenotype. Of the five isolates linked with Thailand, four were from heterosexual men whereas the two Mtr strains linked with London were from homosexual men.

Table III shows the distribution of envelope phenotype in relation to site of isolate and homosexual or heterosexual acquisition. The proportion of Mtr-phenotype strains among rectal isolates from homosexual men is not significantly different from the proportion of Mtr strains among rectal isolates from women $\left(\chi^{2}=0.04 ; p>0.8\right)$. However, a significantly higher proportion of urethral isolates from homosexual men had the Mtr phenotype when compared with genital isolates from heterosexual men and women $\left(\chi^{2}=21 \cdot 3 ; p<0 \cdot 001\right)$. Likewise, a significantly higher proportion of throat isolates from homosexual men had an Mtr phenotype when compared with throat isolates from heterosexual men and women $\left(\chi^{2}=10 \cdot 8 ; p=0.001\right)$. With the isolates

TABLE I

Distribution of cell-envelope phenotypes among isolates from homosexual and heterosexual patients

\begin{tabular}{ccccc}
\hline & \multicolumn{4}{c}{$\begin{array}{c}\text { Number (and percentage) of isolates } \\
\text { from each patient group with } \\
\text { the following envelope phenotype }\end{array}$} \\
\cline { 2 - 5 } Patient & Env & Wild type & Mtr & Total \\
\hline Group & & & & \\
Homosexual & & & \\
men & $0(0)$ & $12(60)$ & $8(40)$ & 20 \\
$\begin{array}{c}\text { Heterosexual } \\
\text { men }\end{array}$ & $9(8)$ & $103(89)$ & $4(3)$ & 116 \\
Women & $8(5)$ & $137(91)$ & $6(4)$ & 151 \\
Total & $17(5.9)$ & $252(87.8)$ & $18(6.3)$ & 287 \\
\hline
\end{tabular}


TABLE II

Envelope phenotype and serogroup of 14 isolates from male infections acquired outwith the Edinburgh area

\begin{tabular}{|c|c|c|c|}
\hline $\begin{array}{l}\text { Country or area } \\
\text { infection acquired }\end{array}$ & $\begin{array}{l}\text { Envelope } \\
\text { phenotype }\end{array}$ & $\begin{array}{c}\text { CoA } \\
\text { serogroup }\end{array}$ & $\begin{array}{l}\text { Patient } \\
\text { group }\end{array}$ \\
\hline Thailand & Mtr & WII & Homosexual \\
\hline Thailand & Mtr & WII & Heterosexual \\
\hline Thailand & Mtr & WII & Heterosexual \\
\hline Thailand & Mtr & WII & Heterosexual \\
\hline Thailand & Mtr & WII/III & Heterosexual \\
\hline Kenya & Wild type & WII & Heterosexual \\
\hline Spain & Wild type & WI & Homosexual \\
\hline Germany & Wild type & WII & Homosexual \\
\hline London & Mtr & WII & Homosexual \\
\hline London & Mtr & WII & Homosexual \\
\hline London & Wild type & WII & Heterosexual \\
\hline England & Wild type & WII & Heterosexual \\
\hline Northern Ireland & Wild type & WII & Heterosexual \\
\hline Inverness & Wild type & WII & Heterosexual \\
\hline
\end{tabular}

TABLE III

Cell-envelope phenotype in relation to patient group and site of isolation

\begin{tabular}{|c|c|c|c|c|c|}
\hline \multirow{2}{*}{$\begin{array}{l}\text { Patient } \\
\text { group }\end{array}$} & \multirow{2}{*}{$\begin{array}{l}\text { Site of } \\
\text { isolation }\end{array}$} & \multicolumn{4}{|c|}{$\begin{array}{l}\text { Number (and percentage) of } \\
\text { isolates with the following } \\
\text { envelope phenotype }\end{array}$} \\
\hline & & Env & Wild type & Mtr & Total \\
\hline $\begin{array}{l}\text { Homosexual } \\
\text { Men }\end{array}$ & $\begin{array}{l}\mathrm{U} \\
\mathrm{R} \\
\mathrm{T}\end{array}$ & $\begin{array}{l}0(0) \\
0(0) \\
0(0)\end{array}$ & $\begin{array}{l}3(50) \\
8(89) \\
1(20)\end{array}$ & $\begin{array}{l}3(50) \\
1(11) \\
4(80)\end{array}$ & $\begin{array}{l}6 \\
9 \\
5\end{array}$ \\
\hline $\begin{array}{l}\text { Heterosexual } \\
\text { Men }\end{array}$ & $\begin{array}{l}\mathrm{U} \\
\mathrm{T}\end{array}$ & $\begin{array}{l}9(9) \\
0(0)\end{array}$ & $\begin{array}{l}90(87) \\
13(100)\end{array}$ & $\begin{array}{l}4(4) \\
0(0)\end{array}$ & $\begin{array}{r}103 \\
13\end{array}$ \\
\hline Women & $\begin{array}{l}\mathrm{G} \\
\mathrm{R} \\
\mathrm{T}\end{array}$ & $\begin{array}{l}4(4) \\
2(7) \\
2(11)\end{array}$ & $\begin{array}{l}98(93) \\
25(89) \\
14(78)\end{array}$ & $\begin{array}{l}3(3) \\
1(4) \\
2(11)\end{array}$ & $\begin{array}{r}105 \\
28 \\
18\end{array}$ \\
\hline Total & & $17(5 \cdot 9)$ & $252(87 \cdot 8)$ & $18(6 \cdot 3)$ & 287 \\
\hline
\end{tabular}

$\mathrm{U}=$ urethra; $\mathrm{G}=$ female genital; $\mathrm{R}=$ rectum; $\mathrm{T}=$ throat .

from homosexual men there were considerably more Mtr phenotypes among urethral and throat isolates than among rectal isolates $\left(\chi^{2}=3 \cdot 71 ; 0.1>p>0.05\right)$.

Table IV shows the distribution of envelope phenotype in relation to CoA serogroup and patient group. All isolates from homosexual men, $57 \%$ from heterosexual men and $52 \%$ from women were of serogroup WII (including WII/III). With regard to envelope phenotype, $13(72 \cdot 2 \%)$ of the 18 Mtr strains and $151(56 \cdot 1 \%)$ of the 269 non-Mtr strains were serogroup WII; this difference is not significant at the $5 \%$ level $\left(\chi^{2}=1 \cdot 2 ; p>0 \cdot 2\right)$. However, the Mtr phenotype occurred significantly more often among WII isolates from homosexual men than among WII isolates from heterosexual men $\left(\chi^{2}=14.3 ; p<0.001\right)$ and women $\left(\chi^{2}=20.4 ;<p 0.001\right)$. In heterosexual men and women there was no significant difference in the distribution of Mtr 
TABLE IV

Relationship of cell-envelope phenotype with patient group and $\mathrm{CoA} W$ serogroup

\begin{tabular}{|c|c|c|c|c|c|}
\hline \multirow{2}{*}{$\begin{array}{l}\text { Patient } \\
\text { group }\end{array}$} & \multirow{2}{*}{$\begin{array}{c}\text { CoA } \\
\text { serogroup }\end{array}$} & \multicolumn{4}{|c|}{$\begin{array}{l}\text { Number (and percentage) of } \\
\text { isolates with the following } \\
\text { envelope phenotype }\end{array}$} \\
\hline & & Env & Wild type & Mtr & Total \\
\hline \multirow[t]{2}{*}{$\begin{array}{l}\text { Homosexual } \\
\text { men }\end{array}$} & $\begin{array}{c}\text { WI } \\
\text { WII or }\end{array}$ & $0(0)$ & $0(0)$ & $0(0)$ & 0 \\
\hline & WII/III & $0(0)$ & $12(60)$ & $8(40)$ & 20 \\
\hline \multirow{2}{*}{$\begin{array}{l}\text { Heterosexual } \\
\text { men }\end{array}$} & $\begin{array}{c}\text { WI } \\
\text { WII or }\end{array}$ & $6(12)$ & $43(86)$ & $1(2)$ & 50 \\
\hline & WII/III & $3(4 \cdot 5)$ & $60(91)$ & $3(4 \cdot 5)$ & 66 \\
\hline \multirow[t]{2}{*}{ Women } & $\begin{array}{c}\text { WI } \\
\text { WII or }\end{array}$ & $4(5 \cdot 5)$ & $65(89)$ & $4(5 \cdot 5)$ & 73 \\
\hline & WII/III & $4(5)$ & $72(92)$ & $2(3)$ & 78 \\
\hline Total & & $17(5 \cdot 9)$ & $252(87 \cdot 8)$ & $18(6 \cdot 3)$ & 287 \\
\hline
\end{tabular}

* A total of 17 strains serogrouped as WII/III: 3 from homosexual men; 5 from heterosexual men and 9 from women.

strains $\left(\chi^{2}=0.005 ; \mathrm{p}>0 \cdot 9\right)$ or Env strains $\left(\chi^{2}=0 \cdot 7 ; \mathrm{p}>0 \cdot 3\right)$ between serogroups WI and WII (including WII/WIII).

\section{Discussion}

Of 287 unselected gonococcal strains isolated from infections acquired in the Edinburgh area $252(87.8 \%)$ had a wild-type phenotype, $17(5.9 \%)$ had a Env phenotype and $18(6.3 \%)$ had Mtr phenotypes. Morse et al., (1982) found $128(82.9 \%)$ wild type strains, $7(4.6 \%)$ Env strains and $19(12.5 \%)$ Mtr strains among 152 isolates collected during a 5-year period. Although the genotypes of our isolates were not confirmed by transformation experiments, the proportions of Env and wild-type phenotypes are similar in the two studies. In spite of a significantly lower proportion of Mtr strains in our series $(p<0.05)$ we confirm the findings of Morse et al. (1982) that Mtr strains are significantly more prevalent among isolates from homosexual men than among those from heterosexual men and women $(p<0 \cdot 001)$. However, our findings cast doubt on the hypothesis (Morse et al., 1982) that the rectal environment, essential for the transmission of gonococci within the homosexual population, exerts a selective pressure favouring the emergence of the Mtr phenotype. We found Mtr strains considerably more often among urethral and throat isolates from homosexual men than among rectal isolates; and Mtr strains were no more common among male rectal isolates than female rectal isolates $(p>0 \cdot 8)$.

The lack of association between the Mtr phenotype and male rectal isolates was surprising. Eisenstein and Sparling (1978) reported that the mtr mutation consistently resulted in reduced rates of exponential growth in enriched broth cultures, whereas introduction (by transformation) of an env mutation resulted in partial restoration to normal growth rates in vitro. Therefore, $m$ tr mutants may be less able to establish rectal infection as their poorer growth characteristics could make them less capable of competing with the complex microbial flora of the rectum. 
In homosexual men, serogroup WII predominates regardless of anatomical site of isolation and has been shown to account for $94 \%, 90 \%$ and $81 \%$ of rectal, urethral and throat isolates respectively (Reid and Young, 1984). Although the Mtr phenotype has been reported to be strongly correlated with CoA serogroup WII (Morse et al., 1982), our data (table IV) show that this applies only to WII strains isolated from homosexual men; strains isolated from heterosexuals show no correlation between $\mathrm{Mtr}$ and CoA serogroup WII. It would appear, therefore, that CoA serogroup WII and the Mtr phenotype are selected independently in the homosexual population rather than by a close genetic linkage.

Our results suggest that the rectal environment is not responsible for selection of Mtr phenotypes. The report of an Mtr-independent system (McFarland et al., 1983) for resistance to faecal lipids also casts doubt upon the role of hydrophobic compounds in the rectal environment in selecting gonococcal strains with reduced membrane permeability. We consider it likely that the rectal environment is not responsible for selecting serogroup WII but that a more general selective pressure such as exposure to antibiotics common to all infected sites is the driving force for CoA WII and Mtr selection in isolates from homosexual men. The following associations between serogroups and antibiotic sensitivity observed in other geographical areas support our hypothesis.

Gonococcal strains with decreased susceptibility or so-called multi-resistant strains belong to serogroups WII and WIII whereas those highly sensitive to $\beta$-lactam antibiotics, tetracyclines and other antibiotics belong to serogroup WI (Bygdeman, 1981b). Bygdeman et al. (1982) confirmed a genetic linkage between serogroup specificity and antibiotic multi-resistance. Although the resistance pattern of the WII transformants studied was very similar to that resulting from the $m t r$ locus, there was no increase in the $52000-\mathrm{mol}$. wt protein associated with the mtr mutation. Further transformation experiments are required to determine the precise nature of the genetic locus.

Bygdeman et al. (1983) considered that greater antibiotic pressure in larger towns than in smaller ones might account for their observed higher incidence of WII strains in larger towns. Isolates from infections acquired in the Far East, where antibiotic pressure is very high because of the lack of antibiotic control, exhibit reduced sensitivity to a wide variety of antibiotics and are predominantly of serogroups WII and WIII (Bygdeman, 1981b). Our serogrouping of a limited number of strains supports these findings and demonstrates a high incidence of the Mtr phenotype among heterosexual men (table II).

The similarity in the serogroup and envelope phenotype of isolates from homosexual men and those from the Far East suggests that the same selective pressure may be responsible. Homosexual men experience a wider spectrum and a higher rate of sexually transmitted diseases than heterosexual men (Fluker, 1976; Willcox, 1981). Although difficult to prove, it is likely that overall antibiotic usage is greater among homosexual men than among heterosexuals. Evidence for antibiotic selection independent of serogroup WII was reported by Bygdeman (1981a) who found that serogroup-WI isolates from homosexual men were more resistant to penicillin than were unselected WI isolates.

It is not unexpected that such differences which most likely result from antibiotic pressure should also occur within serogroup WI because the different protein antigens 
representing serogroups WI, WII and WIII act as "porins", enabling selective passage of molecules across the cell wall (Douglas et al., 1981). However, the proteins IA (representing serogroup WI) and IB (representing serogroups WII and WIII) (Sandstrom et al., 1982) have different structures and orientations in the outer membrane (Barrera and Swanson, 1984) and differ significantly in apparent pore size (Blake, personal communication cited by Barrera and Swanson, 1984). These differences may account for the preferential selection, in response to antibiotic pressure, of protein-IB antigens among isolates from homosexual men.

We thank Professor J. G. Collee for his helpful advice in the preparation of this paper. K. G. R. gratefully acknowledges receipt of a Faculty of Medicine Scholarship.

\section{REFERENCES}

Barrera O, Swanson J 1984 Proteins IA and IB exhibit different surface exposures and orientations in the outer membranes of Neisseria gonorrhoeae. Infection and Immunity 44: 565-568.

Bygdeman S 1981a Gonorrhoea in men with homosexual contacts. Serogroups of isolated gonococcal strains related to antibiotic susceptibility, site of infection and symptoms. British Journal of Venereal Diseases 57:320-324.

Bygdeman S $1981 b$ Antibiotic susceptibility of Neisseria gonorrhoeae in relation to serogroups. Acta Pathologica et Microbiologica Scandinavica Section B 89:227-237.

Bygdeman S, Backman M, Danielsson D, Norgren M 1982 Genetic linkage between serogroup specificity and antibiotic resistance in Neisseria gonorrhoeae. Acta Pathologica et Microbiologica Scandinavica Section B 90:243-250.

Bygdeman S, Danielsson D, Sandstrom E 1983 Gonococcal W serogroups in Scandinavia. A study with polyclonal and monoclonal antibodies. Acta Pathologica et Microbiologica Scandinavica Section B 91:293-305.

Douglas J T, Lee M D, Nikaido H 1981 Protein I of Neisseria gonorrhoeae outer membrane is a porin. FEMS Microbiology Letters 12:305-309.

Eisenstein B I, Sparling P F 1978 Mutations to increased antibiotic sensitivity in naturallyoccurring gonococci. Nature 271:242-244.

Fluker J L 1976 A 10-year study of homosexually transmitted infection. British Journal of Venereal Diseases 52:155-160.

Guyman L F, Walstad D L, Sparling P F 1978 Cell envelope alterations in antibiotic-sensitive and -resistant strains of Neisseria gonorrhoeae. Journal of Bacteriology 136:391-401.

Johnston K H, Holmes K K, Gotschlich E C 1976 The serological classification of Neisseria gonorrhoeae. 1. Isolation of the outer membrane complex responsible for serotypic specificity. Journal of Experimental Medicine 143:741-758.

McFarland L, Mietzner T A, Knapp J S, Sandstrom E, Holmes K K, Morse S A 1983 Gonococcal sensitivity to faecal lipids can be mediated by an Mtr-independent mechanism. Journal of Clinical Microbiology 18:121-127.

Maier T W, Beilstein H R, Zubrzycki L 1974 Multiple antibiotic resistance in Neisseria gonorrhoeae. Antimicrobial Agents and Chemotherapy 6:22-28.

Maier T W, Zubrzycki L, Coyle M B 1975a Genetic analysis of drug resistance in Neisseria gonorrhoeae: Identification and linkage relationships of loci controlling drug resistance. Antimicrobial Agents and Chemotherapy 7:676-681.

Maier T W, Zubrzycki L, Coyle M B, Chila M, Warner P 1975b Genetic analysis of drug resistance in Neisseria gonorrhoeae: Production of increased resistance by the combination of two antibiotic resistance loci. Journal of Bacteriology 124:834-842.

Maness M J, Sparling P F 1973 Multiple antibiotic resistance due to a single mutation in Neisseria gonorrhoeae. Journal of Infectious Diseases 128:321-330.

Morse S A, Lysko P G, McFarland L, Knapp J S, Sandstrom E, Critchlow C, Holmes K K 1982 Gonococcal strains from homosexual men have outer membranes with reduced permeability to hydrophobic molecules. Infection and Immunity 37:432-438. 
Reid K G, Young H 1984 Serogrouping Neisseria gonorrhoeae: correlation of coagglutination serogroup WII with homosexually acquired infection. British Journalof Venereal Diseases 60: 302-305.

Sandstrom E, Danielsson D 1980 Serology of Neisseria gonorrhoeae. Classification by coagglutination. Acta Pathologica et Microbiologica Scandinavica Section B 88:27-38.

Sandstrom E G, Chen K C S, Buchanan T M 1982 Serology of Neisseria gonorrhoeae: Coagglutination serogroups WI and WII/WIII correspond to different outer membrane Protein I molecules. Infection and Immunity 38:462-470.

Sarubbi F A, Sparling P F, Blackman E, Lewis E 1975 Loss of low- level antibiotic resistance in Neisseria gonorrhoeae due to env mutations. Journal of Bacteriology 124:750-756.

Willcox R R 1981 The rectum as viewed by the venereologist. British Journal of Venereal Diseases 57:1-6.

Young H, Paterson I C, McDonald D R 1976 Rapid carbohydrate utilization test for the identification of Neisseria gonorrhoeae. British Journal of Venereal Diseases 52:172-175.

Young H 1978 Cultural diagnosis of gonorrhoea with modified New York City (MNYC) medium. British Journal of Venereal Diseases 54:36-40. 